\title{
The Africanization of Democracy - Elections and Conflict Prevention in Sub-Saharan Africa
}

\author{
Jose Pascal da Rocha ${ }^{1, *}$, Ratha Khuon ${ }^{2}$ \\ ${ }^{1}$ Columbia University, New York, USA \\ ${ }^{2}$ Teachers College, New York, USA
}

Copyright $@ 2018$ by authors, all rights reserved. Authors agree that this article remains permanently open access under the terms of the Creative Commons Attribution License 4.0 International License

\begin{abstract}
This paper explores the lessons learned from the nexus between elections and conflict prevention. It underscores that electoral processes are linked to democratic control by the citizens and, thus, paramount to good governance and accountability of political actors. These factors contribute legitimacy to the governments and, ultimately, promote conflict prevention, conflict transformation, and peace infrastructures. Drawing on the cases of Benin and Uganda, this study will examine the conditions and variables of the contexts that either support or hinder leaders to relinquish power according to constitutional term limits, explore the role of political parties and non-governmental organizations as intermediaries of civic dialogue between the governments and their citizens, and elaborate on the prospects of project democracy and its linkages to peace infrastructures and conflict prevention.
\end{abstract}

Keywords Elections, Conflict, Prevention, Africa, Benin, Uganda, Democracy, Governance, Political Parties, Complexity

\section{Overview}

Electoral processes have the potential to offer a safe, predictable, rule-bound method for arbitrating political and social conflicts through the selection of representatives or the definitive resolution of questions before the community. When elections follow transparent, fair, and independently monitored processes, they imbue the government with legitimacy, garnered by the consent of the people.[1] Credible elections improve the capacity of the state to ensure community security under the rule of law and improve levels of human development through effective governance. These elections create legitimate governments that enjoy popular support for programs and policies. On the other hand, electoral processes are contests through which political power is retained or pursued and social differences are highlighted by candidates and parties in campaign for popular support. In some countries in Sub-Saharan Africa, including Benin, Cape Verde, and Ghana, electoral democracy has brought political competition's positive effects, including responsive government, a wider scope for civil liberties, social justice, and the like. In other countries, however, including Nigeria, Zimbabwe, and Rwanda, for example, elections have yielded nothing more than a standstill in political transitions and democracy dividends. Most recently, events in Senegal and Mali illustrated how variably the cause of democratization is faring in Africa. In Senegal, an incumbent extended his term limit on a technicality but lost the election and stepped down. In Mali, a portion of the army took over in a coup a month before the elections but yielded to an interim government. These examples highlight the complexity of democratic practices on the continent. It has been 20 years since the first national dialogue process led to a new constitution and multi-party systems, in some cases, as early as 1990 . However, only 25 percent of African states show signs of democratic consolidation. Another 43 percent remain autocratic while the rest remain ambiguous in their regime orientation. Overall, the process of democratization has slowed down and in some places reversed.

One of the structural obstacles to democracy on the continent is the waning commitment of the political elites to the democratization project. Furthermore, the supply of democratic goods, in particular, good governance and accountability, has become increasingly scarce. Even in Ghana, a country hailed as the beacon of African democracy in the Sub-Saharan region, there has been a recent spate of corruption scandals and subsequent government reprisals against those who expose wrongdoing, despite strong whistleblower protections. Thus, the question is what is hindering the progress of democracy on the continent, how to revive the process and what are the prospects for democratic development in the 
future?

\section{Democratic Trends}

Over the past several decades, most African countries have seen four major democratic trends:

(1) The embrace of elections;

(2) The acceptance of constitutional norms;

(3) The emergence of free media and an active civil society; and

(4) The establishment of regional pro-democratic conventions and protocols.

In reference to the first trend, the ballot box has replaced the military coup as the chief instrument for changing governments and electing political leaders. The holding of regularly scheduled and increasingly competitive elections has become the norm in Africa. The number of multiparty elections for the executive has risen significantly over the past two decades, from an average of slightly less than one per year (1960-89) to around seven per year (1990-2012). Though, only about a fifth of these contests have led to a change in leadership.[2] Indeed, the number of "electoral democracies" has risen in Sub-Saharan Africa. Out of the region's 54 countries, there was just a handful in the early 1990s. By 2013, there were 19 and, according to the Freedom House ranking for 2016, the region's number of "electoral democracies" has further increased to 32. [3] The growing acceptance of the ballot box as the sole means, by which political power can be legitimately acquired, is undermined by the intensity of the conflict and violence that so often accompany the electoral process. Candidates, parties, and their supporters often treat elections as do-or-die affairs, and election campaigns tend to be as acrimonious and violent as they are colorful. It is not uncommon for parties and candidates to resort to all manner of vote-rigging schemes in their quest to keep or take power. Ruling presidents and parties flagrantly exploit the advantages of incumbency, abuse resources, and unleash physical intimidation against voters in the pursuit of victory.

Typically, democracy on the African continent has been coined as 'failed' or 'weak'. One of the main cited barriers for establishing democracy and strong states in Africa is the prevalence of the neo-patrimonial rule. Neo-patrimonialism refers to the collision between pre-existing patrimonial forms of political organization and the modern colonial state. The term patrimonialism refers to political systems in which leaders derived their authority from their position at the apex of a family or an ethnic community. In such traditional environments, those in power were able to loot state resources to their own, often personal advantage, and were only constrained by local norms and expectations in the absence of effective formal institutions. When such forms of cultural governance at the local level fuse with modern, mostly imported state structures, both were radically transformed. This led to the creation of a new theoretical framework: neo-patrimonialism. There is the appearance of a modern state with its modern apparatus yet with the internal dynamics of a local fiefdom. Therefore, post-colonial Africa is characterized by strong presidents and weak institutions. The collision of pre-colonial authority structures and colonial rule also served to embed the logic of traditional forms of rule into the architecture of the state. It is important to highlight this, since current political practices on the African continent do not always distinguish between the public and the private realm, thus, providing the layers and the foundation for corruption and abuse of power. The ability of leaders to construct personal networks within the state enabled them to undermine important checks and balances in order to bypass constitutional and legal constraints. As a result, postcolonial state institutions and bureaucracies did not evolve based on merits or accountability. Instead, they became vehicles of certain sections of the population with a claim on the executive or with privileged access to right-bearers. However, the theory of neo-patrimonialism cannot be applied as a generic concept onto all African states. South Africa, Botswana, Mauritius, and Senegal are some of the countries that can showcase a resistance to neo-patrimonialism through viable institutions, a history of political inclusivity, and smoother political transitions to democracy. Yet, it is vital to reflect on the social practices that enable the presence or absence of neo-patrimonialism and how this shapes the prospect of reforming the state.

Democratization is an iterative process composed of a number of incremental steps. It is advanced when democratic rules are followed and set back when they are broken. In one of the few attempts to identify the micro-processes that may connect turnover and democratic consolidation in Africa Moehler and Linberg [4] have recently identified that turnover serves to reduce the gap in trust in the state's institutions between winners and losers. Although this positive effect of turnovers erodes over time, in the short run, alternations in power help "to establish a self-reinforcing equilibrium by providing incentives for elites on both sides to play by the democratic rules of the game".[4 p1463] But even this concept is complex in practice. In Benin, the process has been far from straightforward. In 1991, Prime Minister Nicéphore Soglo won the election which led to a steady process of democratic consolidation. However, Mathieu Kérékou, the authoritarian leader who lost the founding election, made a remarkable political comeback and regained power in 1996. While turnover in power aided the consolidation process, it did not permanently remove the leader of the ancien régime.

In order to consolidate all the varying processes, several aspects and dimensions have to be addressed and considered as 'Project Democracy':

(1) deepening the quality of democracy based on the evolution of institutions that are not controlled by the executive, enable opposition parties to be part 
of a level playing field, and curb corruption of the political system by strengthening the judiciary and legislative organs in relations to executive powers;

(2) guaranteeing that historically marginalized groups and the periphery are able to communicate their needs and grievances effectively;

(3) securing democratic gains through the strengthening of democratic norms, practices, and procedures above and beyond political institutions, including political parties, youth organizations, unions, and society at large, promoting pluralism in politics;

(4) designing political institutions that encourage political stakeholders, including rebel and armed groups to be persuaded into investing in multi-party politics;

(5) adapting constitutions to local circumstances in order to achieve more inclusive institutional arrangements and in order to take into consideration variations in historical pathways to democracy.

The context of democratization matters in evaluating the ways in which electoral processes may contribute to peace or to violence. The current literature tends to focus on the following categories, which will also be used in this paper for the sake of case study selection:

(1) countries in transition.[5]

(2) consolidating democracies.[6]

(3) post-war societies;[7] and

(4) referendums to ratify peace agreements.[8]

Another important factor in evaluating the conditions under which elections foster peace or stimulate violent conflict is the strong impact that specific types of electoral systems have on conflict management.[9] Among the critical linkages between the type of electoral system and electoral violence, we can find:

(1) the structure of the party system (indicator of power and social divisions);

(2) the ways in which candidates craft their appeals (indicator for geographical dispersion of votes);

(3) the overall character of the contest (electoral system and the rules of competition for power).

Countries with considerable social divisions, especially along ethnic, religious, or other identity lines, often seek to move from a winner-take-all system to one that arguably more consistently mirrors the diversity of the electorate in legislative or representative bodies. However, there is no single best electoral system to fit all contexts.

\section{3 .Typology of Elections-related Conflict}

In emerging democracies, democratic attitudes are unlikely to result from childhood socialization under authoritarian regimes; therefore, losing gracefully and winning benevolently require personal experience of being on the other side.[10-11] Importantly, turnovers are expected to affect popular legitimacy among losers and winners in opposite ways. New winners/ old losers get an extra boost in confidence yet are likely to still be influenced by a legacy of skepticism from their recent experience as outsiders. Old winners/ new losers are likely to lose some of the unwarranted approval but can still be expected to carry with them some of their old views of institutional legitimacy despite the electoral loss. Thus, turnovers should bring winners and losers closer together in their assessment of the legitimacy of their state institutions. In contrast, it is hypothesized that elections without turnovers make repeated losers perceive government as inherently unaccountable and unfair, while repeated winners come to take advantages for granted. Thus, incumbent success at the ballot box, especially if repeated, will create a marked winner-loser gap in perceptions of legitimacy.

The systematic use of violence constitutes a denial of democratic values and rights. It is plausible that electoral violence should have a greater negative impact on the attitudes of losers than winners. Losers are more likely to suffer abuse during campaigns and elections especially if the winning party was an incumbent party, and more likely to bear the brunt of state violence in the post-election period. In addition, citizens who get their favored candidates as leaders (winners) are arguably less likely than losers to be concerned with whether violence affected the outcome of the election. Thus, the hypothesis is that violence leads to a widening winner-loser gap, whereas peaceful elections will be more appreciated by losers than winners and thus be associated with a narrowing of the gap.

Existing research suggests that when individuals believe decision-making procedures are fair, they tend to be more accepting of the outcomes of the process even when outcomes are deemed suboptimal.[11-14] Depending on the socio-political dynamics and key conflict drivers in a specific country setting, electoral conflict can emerge as a fight over perceived incompatibilities. In some instances, perceptions of deficient elections are likely to spill over into decreasing legitimacy for political institutions writ large. Conflict serves as a catalyst of social change, including progressive social change. As such, conflict can be considered to be both constructive and destructive. According to Kriesberg,[15 p2] conflict is a general term that "arises when two or more persons of groups manifest the belief that they have incompatible objectives." He distinguished between constructive and destructive conflict. Constructive conflict can be viewed as a product of communication and is waged using persuasion or promises of benefits. It is characterized by problem-solving approaches. Those who understand conflict constructively recognize the 'others' as legitimate entities and do not threaten their existence. Kriesberg[15] noted that conflicts 
are constructive insofar as they provide a means for an ongoing relationship. Constructive approaches to conflict create a foundation for subsequent conflicts to transpire in a democratic space, shaped by rule of law and citizen engagement. This includes complex processes such as elections. Destructive conflict, on the other hand, is "imposed unilaterally, with little or no regard to the interests and needs of the party imposed upon. The outcome is regarded by one or more parties as oppressive and requiring redress, or as humiliating and requiring revenge”.[16 p158] Destructive conflict, in similar fashion to constructive conflict, gravitates toward its own reproduction; destructive struggles lead to a relationship among the parties in which future conflicts will also be conducted destructively. Fisher[17 p3] argued that "electoral conflict and violence can be defined as any random or organized act or threat to intimidate, physically harm, blackmail or abuse a political stakeholder in seeking to determine, delay, or to otherwise influence an electoral process." Here, political stakeholders include, but are not limited to the entire electorate. The more actual fraud is present, the more likely one finds perceptions of fraud among citizens; yet, perceptions of the extent and importance of fraud tend to be unevenly distributed among winners and losers in Africa due to imperfect information about actual electoral quality. It is plausible to expect that citizens who voted for the winning candidate will tend to believe that most irregularities were inadvertent, results reflect the will of the people, and the system is legitimate. In contrast, losers are more likely to presume that flaws were both purposeful and consequential for electoral outcomes. Whether or not this in itself is sufficient enough to cause concerns for electoral related violence needs to be further explored. For example, there are also examples where violent contests or opposition's rejection of outcomes coincided with power transitions: the 1999 elections in Nigeria, Ghana's 2000 election, and Senegal's election in 2001, thus favoring legitimacy and recurring transition over peaceful elections.

The question therefore is to what extent do specific electoral qualities prevent conflict and if so, which do? Are there any factors which, if unchecked, have the tendency to unravel into dynamics of violence and struggle? Are there any systemic resiliencies in specific dimensions that allow to provide enough checks and balances to absorb shocks and to foster a peace infrastructure which, in return, provides the platform for successful elections and thus conflict prevention?

\section{Methodology}

Two case studies from the Sub-Saharan region have been chosen to explore the linkages between elections and conflict prevention. The choice of a comparative case study was based on the following criteria:
- $\quad$ stable democracies but weak or fragile states

- $\quad$ varying degrees of electoral control by the electoral management bodies

- Francophone and Anglophone countries to highlight the significance of cultural governance at the local level and its impact on the macro level

- from the Gulf of Guinea to the Great Lakes region with implications from the Greater Horn, in reference to factors of urban-periphery, coastal and desert zones, ethnic heterogeneity and homogeneity, and the balance of forces due to the complexity and dynamics of neighboring countries onto the democracy project

- countries with a rampant informal sector, rapid urbanization, medium levels of corruption and high security risks from terrorism and illegal trade and trafficking

- high levels of poverty, high levels of unemployed/underemployed youth, including a low human development index and, therefore, extremely vulnerable to external shocks

- $\quad$ active civil society.

The chosen cases are:

- Benin (presidential elections on March 6th, 2016, consolidating its democracy project and installing the projet de la rupture)

- Uganda (with parliamentary and presidential elections on February 18th, 2016, with the current president Museveni running for a third time, since a multi-party system was introduced in 2005)

The study uses mixed methodology, including desktop research, semi-structured interviews, and process-tracing. Five variables are considered in all case studies in order to analyze dynamics in the emerging democracies on the continent. This analysis may provide a plausible map of what may happen in other nations if they develop more democratic systems.

The dependent variable, legitimate elections leading to conflict prevention, is a multidimensional concept that is preferably analyzed in its various aspects, so a range of five indicators are examined:

(1) the political landscape index variable that sums up emergent socio-political dynamics, including democratization process, political parties, candidates, legitimacy, and credibility;

(2) the electoral system and electoral management bodies indicate whether democratic institutions and mechanisms offer opportunities for fairness, transparency and freedom;

(3) the context of governance and accountability indicates whether citizens feel political institutions offer possibilities to hold leaders accountable

(4) citizen-driven democracy and civil society measures how satisfied citizens are with the way democracy actually works. 
(5) the threat of extremism, terrorism, and climate change-induced pressures on society indicate risks and exposure to shocks, including an assessment of the system's recovery time in the wake of a shock.
The key independent variables at the national level are those theorized earlier: stability as an outcome of electoral transitions, process of democratization, institutional design, and resiliency.

\section{Case Studies}

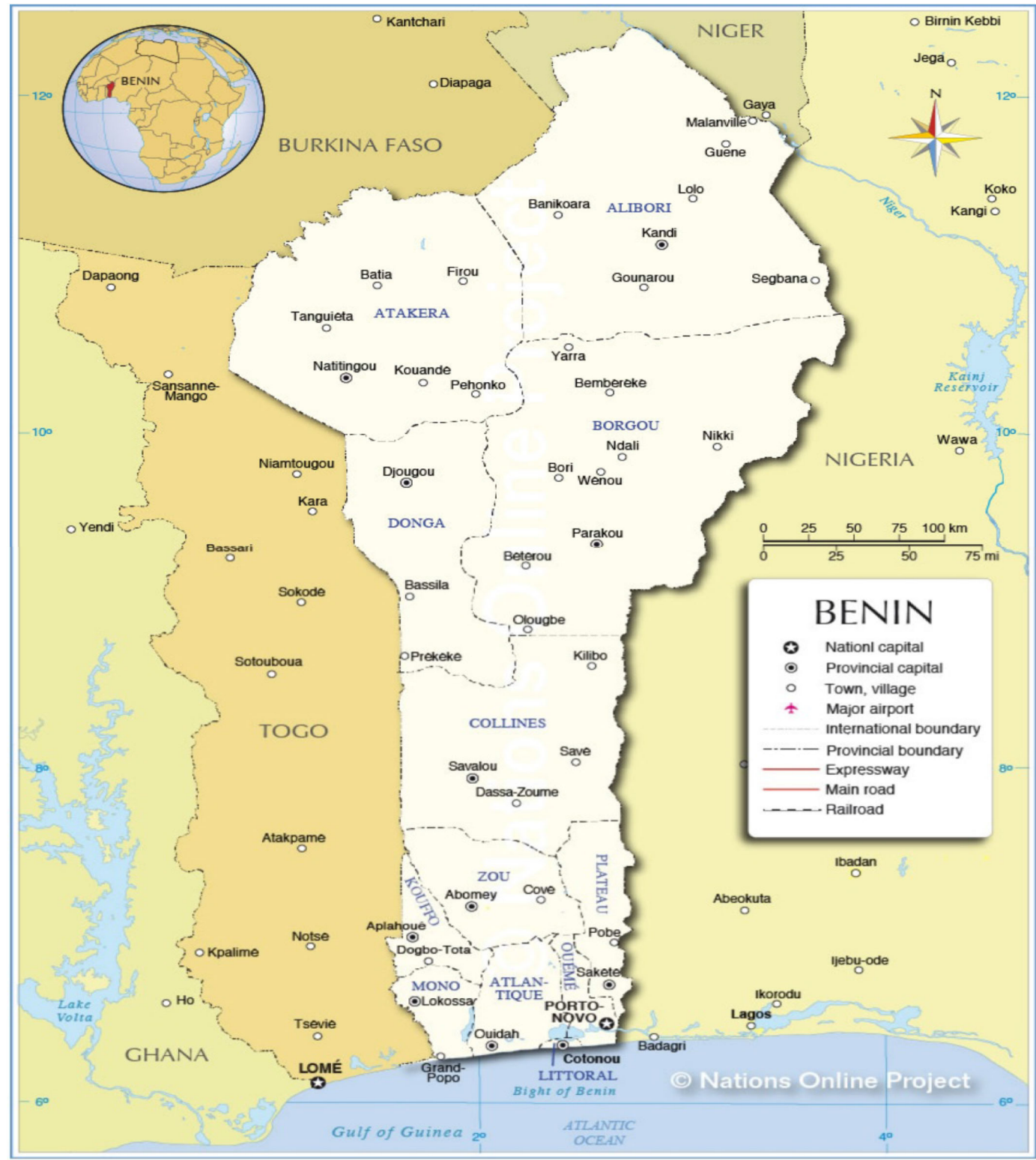

Figure 1. Map of Benin 


\section{Introduction}

Benin has a relatively stable multiparty system, with five successful presidential and legislative elections held since the early 1990s, most of which have been deemed free and fair. However, many democratic challenges remain, both politically and economically.

There are 4 main party alliances and a considerable number of politically unaffiliated individuals or small parties. Political parties are in general very weak, with very few parties working according to an actual structure with members, a manifesto and so on.

Businessman Patrice Talon, known as the "king of cotton", won the 2016 presidential election in a run-off vote in March. In the first round of the election earlier in the month, Mr. Talon came second to Prime Minister Lionel Zinsou, the candidate of the ruling party, who also had the backing of President Boni Yayi. In the run-off, Mr. Talon got $65 \%$ of the votes while Mr. Zinsou secured 35\%. Mr. Talon was formerly a close ally of the outgoing president, Yayi Boni, and he has financed his campaigns for the 2006 and 2011 elections. He fled to France after being accused of involvement in a plot to poison Mr. Boni Yayi in 2012 - an allegation he strongly denies. Mr. Talon received a presidential pardon in May 2014 and returned from exile in October 2015. On taking up his post in April 2016, he pledged to make tackling terrorism and cross-border crime a priority area, and to strive to promote national unity. According to the Benin constitution, the president holds executive powers and heads the government and the armed forces.

\section{Variable 1 - Political Landscape}

Benin's present-day political landscape is scattered. There are many (over 200) different political parties. The Cowry Forces for an Emerging Benin (Forces Cauris pour un Bénin Emergent in French, or FCBE), which is the current presidential coalition, gathers more than 100 different parties. Together with the Democratic Renewal Party (Parti du renouveau démocratique, or PRD), which is led by the president of the National Assembly and the Union Makes the Nation party (L’Union fait la Nation, or UN), they occupy most of the public space. Like in other West African countries, politics in Benin is based on personal interests ('mailbox political parties') and is about patronage and serving clients, predominantly from the politician's native region.

While the country just underwent successful presidential elections, it is interesting for the purpose of this study to explore the trends and contexts leading up to Talon's presidency.

Benin's Constitutional Court postponed the Presidential election scheduled for 28th February to March 6th, 2016 due to the inability of the Liste Electorale Permanente Informatisee (LEPI) Steering and Supervision Council (COS/LEPI) to print and distribute the voters' cards by the initially proposed timeline. The COS/LEPI, established to function from July 1st of every year through to January 31st of the following year, is tasked with the responsibility to print and distribute voter cards and to continuously update the LEPI before making it available for the Autonomous National Electoral Commission (CENA). The postponement was just but one challenge that is reflecting the institutional mechanisms in place to foster the democratization of the public space.

Before the 2011 Presidential elections, Benin had maintained an ad hoc electoral list (only valid for six months) where registrants would have their name written on a sheet of paper. The introduction of the permanent computerised electoral list (LEPI) in 2011 was, therefore, a welcomed development. However, the handing over of the LEPI to the COS/LEPI, a structure comprising mainly politicians ( 9 out of its 11 members are MPs -5 from the majority and 4 from the minority), has been problematic.

For the second time since the adoption of the electronic system, the COS/ LEPI failed to complete the printing and distribution of the voters cards on time. In addition to the inability to guarantee every eligible voter a voter's card to participate in the forthcoming elections, is the questionable validity of previously issued voter's card. New voter's cards were issued in 2015 with the law stipulating that voter's cards can last up to ten years. Initially, whether these voter's cards will be valid in the forthcoming elections was an unanswered question.

However, the Constitutional Court of Benin had ruled that both old and new voter cards can be used for the 6th March Presidential elections. The Court then went further to dissolve COS-LEPI (which according to the electoral code became illegal since January 31st, 2016) replacing it with the Centre National de Traitement (CNT). Like most of francophone countries, Benin operates a mixed Election Management Body (EMB) called Commission Electorale Nationale Autonome (CENA) presently comprising five members (there is no longer a CSO representation). Aside from the weaknesses of the electoral law challenging the work of the CENA, the lack of coordination between the CENA and COS/LEPI has always been a challenge. With the proscription of the latter and introduction of CNT less than a fortnight before the elections are due, coordination is likely to remain a challenge between the CENA and the CNT.

In the run-up to the elections, a total of 47 candidates presented themselves for the polls. However, only 36 were confirmed by the Constitutional Court. 11 others were rejected for various reasons such as the inability to pay about US\$27,000 - candidacy fee, amongst others). Following the Court's decision 3 other candidates withdrew, leaving a total number is down to 33 in the race.

A unique and defining characteristic of Benin is that only independent candidates have been elected presidents since the country joined the third wave of democratisation in 1991. However, the major difference of this Presidential 
poll is the prominence of independent candidates as against political parties. Four out of the five leading candidates are independent (while in the past, only one or maybe two were so). This dominance of independent candidates is connected to the lack of internal party democracy in political parties.

Like in most African countries, candidate selection is a challenge as political godfathers hold sway in terms of who emerges as candidate, irrespective of members' interest. For instance, the ruling coalition in Benin is fragmented due to the adoption of Prime Minister Zinsou (who is considered an outsider) as its presidential candidate. Many of his compatriots in the Les Forces Cauris Pour un Benin Emergent (FCBE) (the ruling and the most important political coalition in the country) are kicking against his selection as the party presidential candidate because they claim this was done against the coalition's internal rules, his dual nationality and his strong link with France. The Parti du Renouveau Democratique (PRD), the third political force in the country (headed by the current Speaker of the National Assembly), and the Renaissance du Bénin (RB), the fourth political force in Benin, had adopted Zinsou as their candidate.

However, Union fait la Nation (UN), another opposition party, and the second most important political coalition, had given the go ahead to members to support any candidate of their choice aside from Zinsou. Other leading candidates vying as independents were Sebastien Ajavon, who heads Benin's National Council of Heads of Companies; Patrice Talon, known as 'the Cotton King', and Pascal Koupaki; former finance minister and Prime Minister of Yayi (for seven years in total). Bio Tchane, a former finance minister supported by a coalition of parties called ABT, is also in the race for the Presidential election.

Another reason for the prominence of independent candidates over political parties is the political party financing regulations. With the gradual but effective decimation of opposition political parties from the time of Mathieu Kerekou, coupled with zero sum politics, political parties in Benin have come to rely solely on private funding to run election campaigns, and most of this money is raised internally from political godfathers and businessmen. It is worth mentioning that the two most important businessmen (and parties' godfathers), Mr. Adjavon and Talon, are among the frontline candidates in the forthcoming elections.

The institutionalization of political parties has been further impeded by the legislation requiring opposition parties to register with the Minister of Interior. Rather than register under the law, political parties prefer to act as opposition (and paradoxically to be officially recognised as such) without following due process. Connected to this is the implementation of the 5 million CFA per MP funding mechanism. The ambiguity of the law, which does not clearly state if the money should go to the parliamentarians or parties, further weakens the party system and fuels corruption. The practice so far has been to dole out this money to political forces to either buy support or votes in parliament when necessary.

The election in Benin brings salient issues to the fore: One is the importance of political parties in a democracy. The absence of viable political parties is affecting democratic consolidation in the region. It is imperative that stakeholders put more efforts in strengthening the political party system. Secondly, there should be adequate legislation to make it as "comfortable" as possible for opposition parties to play their roles. Third, there is a need to reduce corruption and the hijacking of the democratic system by political godfathers. Lastly, are electoral reforms helping to deal with some of the challenges confronting the electoral processes such at the lack of coordination among bodies involved in the management of the electoral processes, and the weaknesses of the electoral code.

\section{Variable 2 - The Electoral System}

There are 4 key observations as to Benin's electoral system:

The first relates to the organisation of the first round by the Autonomous National Electoral Commission (Commission électorale nationale autonome, or CENA). The commission, which became permanent in 2013, seems to have taken on board Lessons Learnt in last year's two elections (municipal and parliamentary elections). The CENA has shown commendable flexibility by allowing voters who hadn't received new voter cards to vote in the first round using their 2015 election cards. First-time voters who had not received voter cards were allowed to cast their ballot using their national identity cards. The CENA has also shown its ability to build consensus by engaging civil society and political parties in the decision to postpone the polling dates, and it has improved its communication by making better use of social media. Another laudable achievement is that the major trends of the election were announced within a reasonable period - 48 hours after the vote. This marks an improvement from the legislative elections of 26 April 2015, where trends were made public five days after the vote.

The second key observation relates to the split of votes among candidates. Having 33 candidates for 4.7 million voters risked fracturing the electorate, but the first round played out between five favourites (Lionel Zinsou, Patrice Talon, Sébastien Ajavon, Abdoulaye Bio Tchané and Pascal Irénée Koupaki), who mobilised more than 90\% of the electorate. They respectively obtained $28.42 \%, 24.73 \%$, $22.96 \%, 8.69 \%$ and $5.87 \%$ of the votes, while the other candidates obtained less than $2 \%$ of the vote each.

Patrice Talon and Sébastien Ajavon, both of them wealthy businessmen, gained around $50 \%$ of the vote. Their popularity seems to confirm that traditional politicians face a crisis of confidence from the population, which often accuse them of being driven by commercial 
ambitions and failing to implement policies.

Talon and Ajavon have, of their own accord, financed candidates in electoral contests in the past. Their portion of the votes gained shows how important financial resources are in electoral campaigning.

Although the geographical distribution of the votes cast in the first-round benefits both candidates running in the second round, the 'game of alliances' that has ensued from the two main alliances formed seems to have worked mostly in favour of Lionel Zinsou. His candidacy is backed by the so-called 'alliance of continuity', which is made up of the ruling Forces Cauris pour un Bénin Emergent (FCBE) coalition, the Parti du Renouveau Démocratique (PRD) and the Renaissance du Bénin (RB).

In the FCBE strongholds in the north and in those of the PRD in Ouémé - mainly in Porto Novo - Zinsou's performance could be attributed to support for outgoing President Yayi Boni (who comes from the north of the country), and Adrien Houngbédji (the president of the PRD, who comes from Porto Novo).

In the traditional strongholds of the RB, (including Zou, Littoral and Atlantic), Zinsou enjoyed less support than expected. His results from the traditional PRD and RB support bases were lower than those obtained by both parties during the 26 April 2015 parliamentary elections, and the 28 June 2015 local elections.

This could indicate that grassroots members of these parties disapprove of Zinsou, or it could point to internal disagreements within these parties, which may have caused dissidences in favour of opposition candidates. Party leaders would have asked their members to vote for Zinsou, but these patterns also show that supporters' compliance is not a given.

Despite Yayi's decision to step down at the end of his second term, these results could also show the population's disapproval of the incumbent president.

Zinsou got $28.42 \%$ of the votes cast in the first round; a relatively low percentage compared to the more than $63 \%$ gained by the candidates of so-called 'alliance for rupture' - namely Patrice Talon, Sébastien Ajavon, Bio Tchané, Pascal Koupaki and Fernand Amoussou. Indeed, Zinsou's result could be interpreted as a protest vote against the incumbent president. It could also be seen to be directed against the PRD and the RB parties, whose decision to join the ruling coalition for the presidential election has been criticised as 'opportunistic', given that both parties were in the opposition up until that point.

The context of this year's elections is not the same as in 2011, but Zinsou's result in the first round can be understood as under-performance of the FCBE, considering that Boni Yayi won the 2011 election in the first round with $52 \%$ of the votes cast.

In the second round, the alliances backing the contesting candidates will have a definitive impact on the outcome of the election. The so-called 'alliance of continuity' of the FCBE-PRD-RB backs Lionel Zinsou, while 'projet de la rupture’ backs Patrice Talon.

Formed on 15 January, the 'projet de la rupture' agreed on a verbal pact to oppose the ruling coalition candidate, Lionel Zinsou, during the second round of the election.

Given the results of the first round, and taking into consideration the ongoing negotiations since the results were announced by the Constitutional Court on 13 March, Talon seems to be in a stronger position than Zinsou. The 'rupture alliance' candidates, who back Talon, gained more than $63 \%$ of the vote after the first round - and Talon has also received the support of more than 20 unsuccessful first-round candidates. On 14 March these candidates including Sébastien Ajavon, who came third in the first round with $22.96 \%$ of the votes cast - signed a memorandum of understanding to support Patrice Talon in the second round.

Talon's performance is even more remarkable given that he came out second in the first round, even though he is running as an independent candidate. Nevertheless, changes within the alliance - or a possible about-turn in favour of Lionel Zinsou - cannot be excluded. Moreover, it is not certain that grassroot voters will vote in line with party leaders' expectations.

Benin's political landscape has changed significantly after the second run. The first round took place against a generally peaceful backdrop, and the challenge is now to conduct a similarly peaceful second round, and ensure transparency and credibility of the results.

President elect Patrice Talon will have the important responsibility to bring together Benin's various political forces to address the challenges of poverty, youth unemployment, corruption and internal security, among others.

\section{Variable 3 - Governance \& Accountability}

Narrowly defined, good governance can simply mean the effectiveness with which a government performs its work and promotes the public good. The public good is largely defined as enforcement of law and order, revenue collection, allocation of resources to meet specific demands, provision of infrastructure and promotion of human rights. Although democracy enhances good governance, the latter is not necessarily equivalent to democracy. Democratic regimes, which are much more open to public scrutiny and periodic tests of legitimacy through elections, tend to be more amenable to good governance. Yet, and as can be seen in the case of Benin, the mere holding of multi-party elections should not be taken as proof of the existence of good democratic governance. While multi-party elections may be symptomatic of the reduction of the more overt repressive character of the authoritarian state, it may hide beneath its processes of political exclusion, discrimination, corruption and mismanagement of public resources as horrendous as they could be in authoritarian states. Elections, by 
themselves, are not enough. A democratic political culture involves deeper participation at local levels, less concentration of political power at the center, institutionalization of the rule of law and respect for human rights, including social rights. In the case of Benin, the presidential elections displayed a range of candidates with a lack of social and political projects as the basis of a political vision. It could be observed that the electorate did tend to gather rather around candidates with money to spend rather than candidates appealing to the reviving of democratic dividends.

A legitimate and democratic system of government needs to be based on the rule of law. This means that, on the basis of rules and regulations laid down by the legislature, implemented by the executive arm of government and adjudicated by the judiciary (in the event of a dispute), individuals will seek to maximize their interests as citizens endowed with rights and obligations by the state. While accepting basic human rights as inalienable, the rule of law assumes every citizen will assimilate the principles and ideals of citizenship as the basis of exercising his or her rights and claiming the same from the state. It has been observed that in Africa, and especially so in Benin, institutionalizing the rule of law has been problematic in two ways. First as a result of colonial rule when individuals were regarded by the state as subjects and not citizens, individuals have continued to relate with the public realm in an alienated fashion. They are much closer to their family and clan ties, which Peter Ekeh regards as "the first public".[18] Hence little regard is given to obligations to obey the law in the "second public", the state. An individual regards it as ethically correct to misappropriate government funds as long as this goes a long way to satisfy family and kinship demands. It is this "politics of two publics" which has buttressed corruption - hence growing underdevelopment and poverty - in spite of the existence of the plethora of laws and regulations against corruption and misuse of public resources.

Second, since individuals seem to benefit from the state only when "one of their own 'privatizes' the state", the significance of citizenship rights has more or less been lost. The services that the state used to provide after independence - education, healthcare, social security and law order - having largely disappeared, individuals do not feel engaged with the state". They do not feel they have a stake "in the second public", hence their propensity to meet public obligations in terms of paying taxes, for example, is low; their interest to claim any entitlement from the state almost negligible. For the rule of law so vital for good governance to be institutionalized, African governments need to "re-engage their peoples" and enhance their citizenship rights. Citizenship rights have been defined as "rights to basic standards of civilized living" which include health, education, shelter, social security, security and human rights. It may be argued that governments in Africa, due to lack of resources, cannot guarantee their citizens such rights. Even if this were the case, they must at least show a commitment to enhancing opportunities for the realization of these rights.

In conclusion, while Benin is still being considered a weak state, it has functioning institutional mechanisms that provide certainty and transparency. Being considered a democratizing country, the Constitution provides key provisions in regards to governance and key accountability measures. While these measures are evident, the progress toward governance and accountability is rather slow. Parliamentary oversight non-existent and the culture of political participation is not well implemented.

\section{Variable 4 - Citizen-driven Democracy}

Citizen's participation in political decision-making processes is rather low and weak. This has to do with a lack of agency, civic education, and a lack of sharing of political and social visions for the society at large. Yet, civil society plays an important role in establishing open channels of communication between citizens and the state and functioning as watchdogs during electoral campaigns and periods. Civil society is very active in Benin. Its historical roots can roughly be schematized along three periods: From 1960 to 1972, Benin had the most vibrant civil society in francophone Africa, and unions and other associations of different types were very active on the political stage. For example, the first military intervention led by General Christophe Soglo was carried out following mass mobilization by civil society demanding a coup. From 1972 to 1990, the Marxist regime incorporated all the groups and associations as representatives of various sections of society into the structures of the single party. In 1989, the formerly incorporated organizations, in particular the unions and the students, began organizing mass protests asking for political and economic reforms [19-20]. They were the main driving force behind Benin's democratic opening. Except for the communist party, political parties were non-existent and were created only after the 1991 national conference. Since then, civil society organizations have continued to flourish and they continue to receive generous attention from donors as a main component of their democracy, governance and rule of law programmes. The media constitutes another important sector for donor support. While Benin used to have only one state TV and one radio station before political liberalization, there are now five private TV channels, more than ten radio stations in Cotonou, numerous rural and commercial radio stations and several dozen newspapers. In addition, there are at least four big media groupings: L'Union des Professionnels des Media du Bénin, la Maison des Media du Bénin, l'Observatoire de la Déontologie et de l'Éthique dans les Media and l'Association des Patrons de Presse. Most of the media are relatively independent from political actors. Yet, journalists rarely have a diploma, or even attend a single journalism course, and this clearly has a 
negative impact on their professionalism as well as their potential contribution to democratic consolidation. Freedom of the press generally is respected in Benin. However, it is rather ironic that this fundamental right generally was better upheld during the presidency of the former dictator, General Mathieu Kérékou's (1996-2006) than during the civilian President Yayi Boni. No journalist was ever jailed during Kérékou's two terms, and writers were not persecuted for their work, regardless of how critical they may have been. By contrast, many journalists have been sued and jailed under Yayi Boni, who seems less tolerant towards accusations of corruption and authoritarian tendencies. Nonetheless, it is not clear whether and to what degree media freedoms are really deteriorating. Journalists are often sued because of the usually unverified and accusatory tone and content of most newspapers, which is a consequence of journalists' lack of professionalism. It is also interesting to point out that during the last presidential elections, social media flourished under the banner of Association Beninoise des Bloggeurs. Teaming up under the banner of a Civil Society Platform, various bloggers were recruited as part of an election monitoring team, scouting and monitoring the blogosphere as to incendiary remarks by social media users, enabling the communication between the Civil Society Platform, and acting as an early warning element in the case of potential early announcement of results. Supported by the donor community, especially the European Union and the United States, this new citizen-driven participatory tool added an important element to the overall governance structure of electoral bodies and agencies.

One observation that can be made is the disconnection between political parties, their elites and citizens. In conversations, citizens do give the impression that whether or not they participate or voice their grievances, political parties are oblivious to demands for more inclusion and participation. This perceptional problem suggests that there is a deeper weakness within Benin's political party system. Observers often highlight the extreme fragmentation of Benin's political scene. As a civil servant working in the political department of the Ministry of Interior told me, no one has a precise idea of the number of political parties in the country. Since the law for registering parties is so liberal, parties are created and dismantled frequently depending on the political issues at stake. Many have a legal existence but few organize regular political activities or participate in elections. The last electoral cycle, however, witnessed the formation of four relatively big coalitions. In addition to the FCBE and the UN, which included the country's main political parties, there was also the Alliance G13 Baobab composed of independent MPs and the ABT coalition that supported the candidacy of Abdoulaye Bio Tchané.

Parties in Benin are portrayed as being exactly the opposite of 'classical' political parties.[21] They are not always permanent organizations, and those that have been around for a while look like the personal property of their 'founding father'. They are hardly present at the national and local levels and most of them look like interest groups that, rather than fighting for power, generally support a potential winner in exchange of spoils in case of victory. This phenomenon, described as 'political nomadism' by Banégas,[22] is best illustrated by the case of the Renaissance du Bénin (RB) coalition that supported former President Nicéphore Soglo. Before the elections, the RB supported the UN coalition but after the elections, it joined the President's FCBE. Rather than winning the electorate's support by designing convincing political and economic programmes, these parties generally specialize in vote buying and electoral clientelism.[23] In an interview, Joseph Gnonlonfoun, former MP in the 1990s and President of the 2011 National Electoral Commission bitterly concluded, parties in Benin have lost their ideological conviction since the first 1991 parliament. He stressed that even though the concepts of majority and opposition are legally defined, no party presents itself as the official opposition. When they oppose the president, their focus is rarely on programmatic political issues but rather on personal attacks in an attempt to garner political capital. The result is a chaotic and constantly changing landscape of fleeting party alliances, as could be seen in the run up to the 2016 presidential campaign, with the coalition of FCRB, PRD and RB, supporting the Prime Minister, but without real social foundation within the party movements. Citizens need to be more involved in the political space for the state to continue reaping the benefits of the continuing democratization process. This would also involve to open up the political dialogue among the political parties and between the political parties and the citizens in order to co-design the various degrees of institutionalization fostering a more transparent and accountable democratic space.

\section{Variable 5 - Threat of Extremism}

Crises in the Sahel (from Mali to southern Tunisia and Libya) and the regionalization of Boko Haram's activities as far [sic] as the Lake Chad basin (Niger, Cameroon and Chad) are some of today's worrying signals related to West African stability.

New religious "ideologies" (Christian evangelism and/or Sunni revivalism), mixed with economic frustrations, have deeply impacted the traditional balance and make long-term stability a challenge for most of the countries in the region, from Mali to the Horn of Africa. The report explores the specific ways the Ghanaian and Beninese actors are dealing with politics, identity and societal stress. It also identifies the influence of external actors, from both the region and beyond, and potential spill-over of nearby conflicts.

\section{Pre- and Post-Colonial Remnants}

A small ruling class takes the political decisions and 
dominates the realities of governance. By extension, this elite also controls the distributive circuits and the most lucrative economic sectors. Many members of this ruling elite were educated in European educational institutions, especially in France, and share the same background. They have developed a close proximity and know each other quite well. 'We know where to find one another when decisions need to be taken or a crisis needs to be solved' is an expression that is often and openly used by members of the ruling class in Benin. This small group of elites runs the country like a private company, with high concern for the protection of their own interests.

Still, there are also some striking typically 'Beninois' characteristics. One of the most important is that, more than in other African countries, the local or indigenous religions were preserved and openly mixed with the imported Islamic and Christian teachings and, more importantly, practices. Another typical characteristic of Benin is the high level of mistrust among individuals.

Since Benin's society is strongly organized along religious affiliations, religious leaders seek to extend their political influence on different levels. Ties with political parties and ministers are strong, and church leaders belong to the small elite group that runs the country.

Historically, the influence of the classic Christian churches has been strong, but was always associated with colonialism. Some of this has changed with the conversion of Benin's present president to Evangelical Protestantism. This fact has further extended the influence of the newcomer, the Evangelic church, at the highest level of government. Benin's Ministry of the Interior and all of the presidential advisors are Evangelists, a fact that has impacted the relations between different societal actors and the balance of power in Cotonou and Porto-Novo. The classic, traditional elite is confronted with reduced access to a number of high-ranking politician.

It is important to note that the Evangelical churches have strong backing from private sources, especially in the United States, and that they represent a new player/power in sub-Saharan Africa.

It is equally important to note that, traditionally, the influence of imams in national politics is, and always has been, limited. Islam was a power in the north, influenced by Arabs, and had its own dynamics and constituency, with little relevance in the high politics of Benin's coastal areas.

Islam is tolerated in Benin, but is not integrated into the national political landscape. With only one Muslim national political leader - Abdoulaye Bio Tchané from the L’alliance Avenir pour un Bénin triomphant (ABT political alliance) - Benin remains largely Christian-dominated. Combined with growing (and sometimes destabilizing) foreign interference on both the Christian and Muslim sides, and parallel to the increasingly intolerant religious discourse in Benin, this low visibility by Muslims may lead to tensions in the future (because of resentment at their marginalization, and political or economic frustration).
Like in Ghana, there is a strong, or at least perceived, 'north-south' divide in Benin. The north of Benin continues to be poor and less developed, where the south holds the economic power. Colonial penetration from the coasts led to north-south 'development' disparities. Because of southern divisions (especially Abomey, Porto-Novo and Mono), politicians often originate from the northern part of the country. This operative equilibrium between the north (holding political power) and the south (which has social and economic influence) has so far succeeded in fostering national unity and in preserving peaceful relationships among Benin's communities.

Although there is a claim that relations among Benin's religions can be described as 'tolerant', much of this tolerance disappears with a slight scratch of a nail. There is an anti-Islamic discourse present in different Christian churches and sermons, on both the Catholic and Evangelist sides. Muslim interviewees in Cotonou, for instance, referred to some pastors' interdiction not to eat meat from the Muslim feast of sacrifice (Tabaski), because eating Tabaski meat would hold the risk of becoming poor.

The anti-Muslim discourse more generally highlights the assumed ambition of Islam to convert Christians to Muslims, as well as the ambition of Muslims to dominate politics. The researchers were warned, on several occasions, by Christian church leaders about the potential for a Sharia law-based state in Benin. The anti-tolerant discourse of the Evangelist churches is wider and targets not only Muslims, but also classical Christian churches.

On the other hand, the more tolerant Sufi interpretation of Islam is being challenged by more purist imported versions. The number of mosques that are being built and the introduction of the veil for girls and women in the north, especially in the city of Djougou, are recent examples of these fundamentalist pressures.

Islamic presence in Benin is old and coincided with the establishment of freedom of association in the 1980s1990s, which encouraged a proliferation of Islamic charitable NGOs and the dissemination of new foreign doctrines. External training for Beninese scholars, especially in Medina in Saudi Arabia, exacerbated these foreign influences. A revival of religious orientation and related Dawa is visibly present. According to some sources, police have stepped in on several occasions in the north against young extremist preachers returning from Saudi Arabia. In Cotonou, a radical Muslim cleric from Congo has also recently been expelled.

These phenomena are catalysed by the fact that youngsters are travelling to the Middle East to receive training and are sponsored to return to preach a different approach to Islam that is purer than local traditional or other syncretic influences. Some imams are, for instance, reported to earn 300,000 FCFA per month (around 450 euros), an amount that cannot come exclusively from local worshippers' contributions. Pockets of more purist groups, which are organized around these individuals and which 
hold a certain societal status based on their studies abroad, form parallel societies, much like those that exist in Ghana. The northern city of Djougou, close to the border with Togo, clearly illustrates this Beninese Islamic revivalism.

The conflict-resolution systems in Benin are strong, in that these are based on the interest of the elite to keep the system in place and stable. This has little to do with the official legal or political procedures. Like in most other similar countries, however, these formal systems hardly function as a legitimate and effective way to solve conflicts.

The existing conflict-resolution system may be able to fix some of the potential upcoming societal divisions. It may also fail, however, because of the described weaknesses. The possibility of failure cannot be excluded, since the external influences are increasingly relevant, and not just because of the influence of organizations in the United States via the Evangelist networks, and the influence of certain forces in the Gulf via students and preachers who are educated in the Middle East, but more directly by security developments in neighbouring Nigeria.

The Nigerian situation is relevant, not just because Benin takes part in the regional coalition against Boko Haram (only at a political level for now, because of the lack of military means available), but also because there are reports about infiltration by, and recruitment for, Boko Haram in Benin. The presence of northern Nigerian imams and Arabic-speaking advisors in the biggest mosque of Benin (in Cotonou city) is one more indication of the interest that Nigerian religious circles have for the situation in Benin.

Like in Ghana, the Wahhabi influence is relevant in Benin. This started in the 1970s, based on scholars returning from the Gulf countries and bringing a purist, anti-Sufi interpretation of Islam to the West African region, including to Benin. The reach and impact of Wahhabism is visible and strong today in some areas of Benin, especially in the north. Although the political elite has tried to reduce the impact of these preachers, it seems that of late the relevance of the elders' voices is diminishing.

Youths feel attracted to this new promise of perspective and guidance and increasingly ignore the voice of a generation that is losing credibility because of the 'politics of the belly'. The lack of (economic) perspective for a new generation provides the last push for youngsters who are seeking a reason to live and die. Like in Ghana, the more aggressive Tabliq doctrine, which is influenced by Pakistanis, has also established cells in Benin.

Benin's real difference with Ghana, however, lies in the fact that Benin's individuals are joining the struggle in neighbouring Nigeria. The level and intensity of these recruitments are yet to be established, as well as the real push factors at play (whether economic or ideological attraction), but this recruitment gives a new dimension to Boko Haram's reach, which has always been believed to be restricted to the geographic area around Maiduguri.

Apparently, the fact that these foreign fighters - who are joining Boko Haram from Benin - do not speak Kanuri or English does not stop the organization from this recruitment activity outside their normal zone of action. According to the researchers' sources in Benin, the recruitment takes place as a routine activity, but exact numbers are not available. The question is whether Benin's traditional elite will be able to respond by giving space to the youth to express their ambitions and perspective, and will facilitate access to resources and politics. 


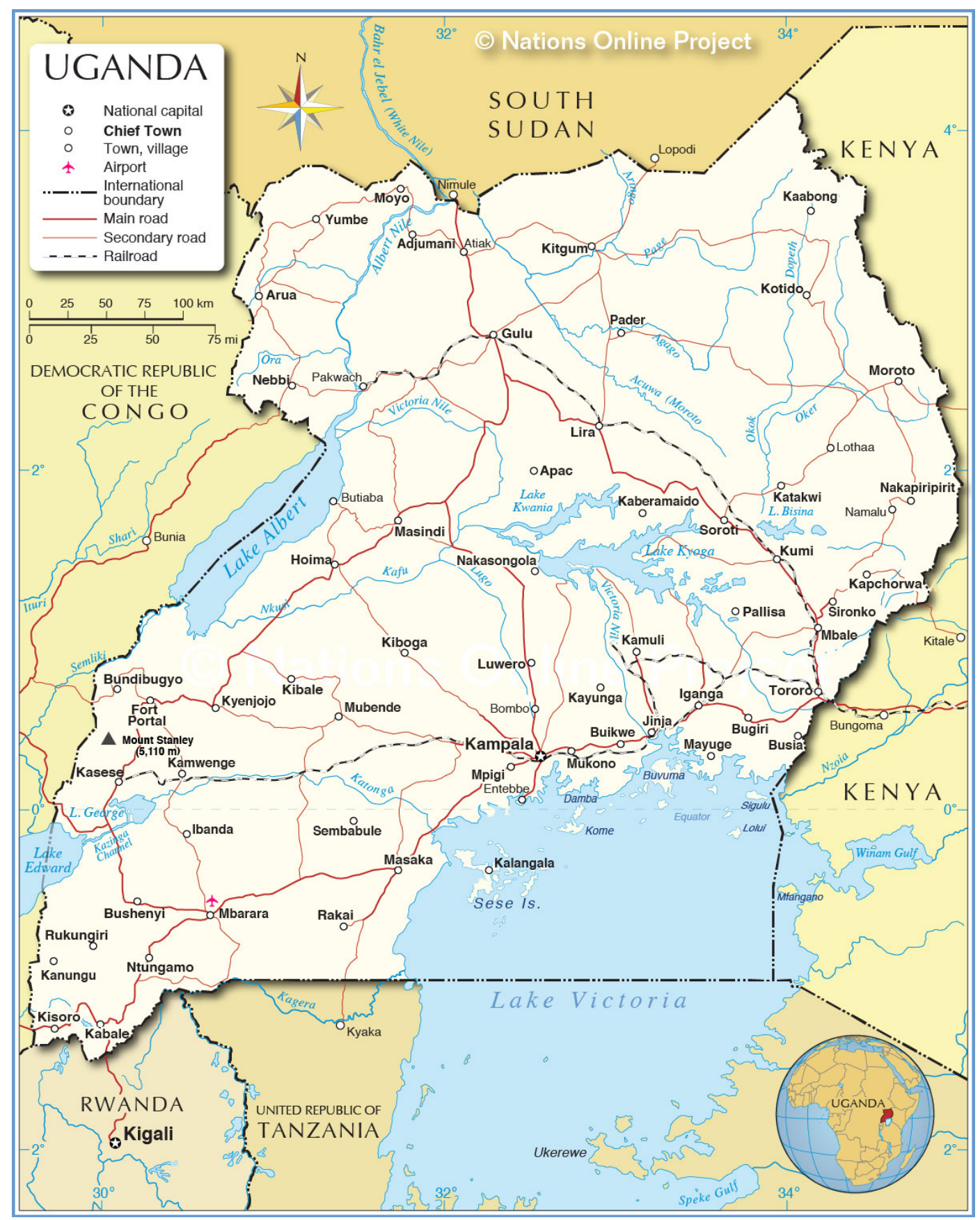

Figure 2. Map of Uganda

\section{Introduction}

Uganda is a landlocked country in Eastern Africa. Kampala is its largest city and capital. With an area of $241,038 \mathrm{~km}^{2}$ Uganda is slightly smaller than the UK or slightly smaller than the U.S. state Oregon. The country's highest point is Margherita Peak on Mount Stanley $(5,110 \mathrm{~m})$, a mountain located in the Rwenzori range within Rwenzori National Park. Spoken languages are English (official), Luganda, a major language of Uganda, Swahili, and other native languages. The map above shows Uganda and the surrounding countries with international borders, the national capital, regions and districts capitals, cities, main roads, railroads and major airports. Border Countries:
Democratic Republic of the Congo (Kinshasa), Kenya, Rwanda, South Sudan, and Tanzania.

Uganda achieved independence from the UK in 1962. The dictatorial regime of Idi AMIN (1971-79) was responsible for the deaths of some 300,000 opponents; guerrilla war and human rights abuses under Milton OBOTE (1980-85) claimed another 100,000 lives. During the 1990s the government promulgated non-party presidential and legislative elections.

\section{Variable 1 - Political Landscape}

Since independence from Britain, Uganda had come under a pattern of tumultuous power struggles waged by its 
leaders. The first post-independence leader, Milton Obote sought to strengthen his own power and the country saw its traditional kingdoms abolished and the constitution suspended. Not long into Obote's rule, the president's military commander, Idi Amin, lead a military coup against the president and Obote was effectively ousted. The country disintegrated into heavy violence under Amin's rule until the Tanzanian army alongside Ugandan exiles invaded the country forcing Amin to flee the country. Obote, interestingly, returned to power through the administration of elections but several years later was ousted again, this time by Tito Okello. Barely half a year had passed until Okello himself was overthrown by the National Resistance Army ledy by Yoweri Museveni. Under the leadership of Museveni, Uganda was finally able to attain relative political stability after decades of political strife. The country's government was placed under the Movement system which was purported to be a no-party system on the basis of preventing further conflict that the presence of multiple parties might have brought. Previously existing political parties that were suppressed in previous governments were still allowed to peacefully re-enter the landscape but under the condition that they refrain from overt political activities unless it was within Museveni's National Resistance Movement (NRM) framework. Many interpreted this system as essentially a one-party system dominated by the NRM. The "No-party" system lasted until the government submitted in 2005 to public calls for a move towards a multi-party system.[24-25]

There are now 29 registered political parties since the multi-party system was initiated and Museveni's government has indeed continued to dominate the political landscape with the opposition generally weak and fragmented. Uganda's main traditional opposition parties, the Conservative Party (CP), Democratic Party (DP), and Ugandan People's Congress (UPC) lost much of their power since the Obote and Amin years and are now blighted with their own internal divisions. Factions from within the DP and the UPC have tended to either support the presidential candidacy of FDC's Kizza Besigye, or, most recently, independent candidate, Amama Mbabazi. Opposition parties have significant strongholds mainly in urban areas, however, the rural areas, making up approximately eighty percent of the country, belong to the NRM.[26-27] The powerful grip that Museveni's NRM has had on the political landscape over the past three decades, however, has shown a signs of slight weakening. The FDC's main flag bearer, Besigye, has come close to becoming a relatively viable presidential contender against Museveni over the last few elections in spite of a restrictive political atmosphere for opposition parties. The opposition landscape has also shown interesting changes as former NRM party members have increasingly splintered off onto their own, as independents. Mbabazi, who ran for president in 2016 as an independent, was one of Museveni’s closest advisors for decades, and is a prime example of this splintering. In an NRM-dominated political landscape, the opposition still shows signs of life, something that was not evident in the early years of Musevini's rule.[26]

In the run-up to the 2016 presidential election, the strongest opponents to incumbent candidate Museveni, were Kizza Besigye and Amama Mbabazi. Besigye, who was Museveni's former physician, had come the closest as a viable contender to Museveni while also being the longest running candidate, having run in the last four elections since 2001. He has lost in every presidential election he has run in since 2001, but he has also received substantial public and media attention, mostly due to continuous arrests, harassment, and physical harm inflicted on him by the NRM government. The rationale for Besigye's treatment given by the government was based on the need to take public security measures.[26,28] Amama Mbabazi, the third strongest candidate, was a former NRM prime minister to Museveni and one of his closest political advisors for decades. However, he was recently fired from his position as prime minister. Thereafter, Mbabazi made his 2016 bid for president as an independent candidate. Observers noted his strong social media presence, however, he garnered less media attention compared to Besigye. The lower media attention placed on him has been attributed to his non-confrontational and less activist-minded qualities compared to Besigye, characteristics that have served the latter well in reinforcing his political relevance.[29] Museveni's 2016 presidential candidacy, the strongest of all the candidates, was nearly indomitable, as in all the other previous presidential elections. He had the pre-existing advantage of possessing substantial financial resources and political capital that enabled him to create conditions restricting opposition candidates from fully and freely campaigning throughout their candidacy on an equal footing. Opposition rallies have been reported to be an environment of exceeding intimidation as government security personnel has, at times, used tear gas and assault rifles to disperse crowds. Media outlets that cover the candidates lean toward the incumbent NRM government. Opposition parties do not have the same access to public media as the dominant party as the NRM has historically held substantial sway over the media landscape. The financial resources that Museveni has at his disposal by virtue of the state coffers made available to him have also enabled him to, what many have seen as an indirect buying of votes as illustrated by his pledge to provide millions of gardening hoes to Ugandan households.[26]

Museveni's NRM party exists in a political landscape that reinforces its dominant status, there is still one segment of the population whose potential votes the political candidates have worked earnestly to attend to: the Ugandan youth. Approximately $70 \%$ of the population are under the age of thirty[27] and a significant challenge that is felt by the segment of the population is their lack of economic opportunities. Some analysts have observed that youth's 
high unemployment rates make them particularly vulnerable to political manipulation. All three 2016 candidates have prudently developed strategies to target the youth demographic during their campaigns. Problematically, however, both Besigye and Museveni have employed youth militias, the Power 10 of the former and the Crime Preventers of the latter, during the elections to help police the electoral atmosphere. Observers have expressed concern that these militias have contributed to a violent atmosphere and may have longstanding problematic implications for youth who are unemployed and who then resort to working for these electoral militias.[26]

\section{Variable 2 - Electoral System}

Uganda's electoral commission (EC) became a permanent institution overseeing the presidential and parliamentary elections after the 1997 Electoral Commision Act was passed by Parliament. Elections since 2001 have operated under this electoral management body's administrative oversight. The EC's functions include overseeing areas of civic education programming, attending to election complaints, oversight of parties and candidates, publishing results of the elections, maintaining voters' register, and demarcating constituencies in line with constitutional boundaries. It has the capacity to make proposals to Parliament regarding electoral reform, though it doesn't have legislative authority. Its general mandate is to ensure regular, free, and fair elections and it is responsible for organizing, conducting, and supervising every elections referenda. Seven electoral commissioners are appointed by the president, then approved by Parliament on 7-year term limits with one-time opportunity for renewal. Observation reveal that EC has had a history of concerns and accusations regarding bias and irregularities throughout a number of the country's elections.[30]

International observers of Uganda's elections since it began in 1996 have witnessed Museveni's victory in every election and the NRM party's continuing dominance in government. The lack of political participation in the 1996 elections was a concern among observers; however, the president's platform call for national unity in the country's aftermath of violent turmoil resonated more loudly than the concerns over potential electoral illegalities taking place.[33] Allegations of electoral malpractice and voter harassment were more pronounced in the following 2001 elections, and the opposition submitted their petitions of protest to the Supreme Court. These allegations were confirmed by the Court though it ruled that the malpractice was not sufficiently substantial to have changed the results of the elections. Opposition candidate, Kizza Besigye, fearing a prison sentence and physical harm, fled into exile after losing the 2001 presidential elections. While newly under the multi-party system (with newly removed presidential term limits), the country's next elections in 2006 provoked concerns regarding the independence of the Electoral Commission. Before the 2006 presidential candidates were formally announced, NRM-linked Attorney General Khiddu Makabuya was discovered contacting the EC and insisting that it prevent Besigye's nomination as president. The rationale given was that Besigye was unfit to run because he was facing arrest charges for treason and rape.[33] Besigye was eventually acquitted of the charges and continued to run for president in 2006, but still lost the elections. The 2006 elections were also marred with allegations of electoral malpractice. Petitions were brought to the Supreme Court, but once again, the court ruled against the opposition citing that the malpractice, though confirmed, was not sufficient to have affected the outcome of the elections.[32] The 2011 elections were regarded as the least violent compared to previous elections. Some observations deemed that it had met the minimum standards of free and fair elections and had been the most organized compared to prior elections.[32,34]

The most recent, 2016 election atmosphere was tenuously calm. Presidential and parliamentary candidates generally campaigned at low-key levels with parliamentary candidates canvassing on smaller parish and village levels, going door to door during neighborhood visits. The atmosphere was reported as generally peaceful in that there were relatively few cases of politically motivated violence. Although it was a calm election, it was also notably repressive as both government and opposition party recruited small militias to keep peace and stand guard over the voting process. After election results were announced, the repressive atmosphere was more pronounced as the government aimed to keep critical voices under control. Besigye, yet again, had been arrested on charges of treason. Meanwhile Mbabazi submitted a petition to the Supreme Court contesting the validity of the results which was ultimately thrown out on the same basis from which previous petitions were thrown out: that there was insubstantial evidence to have changed the results.[26] The Electoral Commission during the 2016 elections continued to lack both independence and transparency. Observers expressed that the administrative conduct of the elections remained flawed. Electoral materials arrived late to polling stations of which many reportedly had an intimidating atmosphere posed by NRM presence, and to a smaller extent, FDC-recruited security personnel. Twenty percent of polling stations observed by the E.U. Mission had unsealed ballot boxes, of which about half was regarded to have compromised voter confidentiality. The integrity of the tallying process had also been compromised. In $85 \%$ of the District Tally Centers observed by the E.U. mission, print-outs of sub-county results, broken down by polling stations, were not distributed and publicized. Furthermore, the manner in which collated results at district levels were transmitted to the EC opened up possibilities for 
mishandling and malpractice. For example, in some districts, the protocol to electronically transmit the collated results was not fully adhered. Observers reported that in some problematic cases, either the electronic transmissions to the EC did not actually occur or the collated results were brought to the EC in-person by a district officer. In these cases the final tallying could not be observed. As the election time period came to a close, the EC was observed to have failed in publicly declaring the results in a timely and transparent manner. It was noted that in some areas, preliminary presidential and parliamentary results were announced even as the elections were happening. When the results were officially declared, they were found to have missing data from $7 \%$ of the polling stations which effectively excluded about 675,0000 votes that were cast.[26] The E.C is mandated to demarcate constituencies in a way that each county has one constituency while meeting a population quota as much as possible by considering such factors as population density and geographical features. While the EC and Parliament followed through on ensuring the one-to-one county-constituency ratio, they neglected the population quota requirement resulting in highly inaccurate population to electoral constituency ratios. This neglect meant that 231 out of 290 constituencies have voter populations that are far from a typical constituency population. The implication of these erroneous ratios is that general equality of votes are highly compromised.[26]

On a broader level, a weak legal framework inhibits Uganda's election from being conducted in a fully free, fair, and transparent manner. The legal framework is rife with loopholes and ambiguities. For those who aspire to run for Parliament, there are conditions that require advanced education credentials and the payment of high nomination fees which would mostly attract those from the privileged classes. Campaign financing are bound by legislative provisions that require the disclosure of party financials but candidates and parties do not adhere to them and the EC does not enforce them. Observers reported of "indirect bribery of votes and abuse of state resources" when Museveni used the 2016/2017 budget to provide 18 million Ugandan shillings goes to 6 million households that were distributed 10 days before the election.[26 p17]

The overall characteristics of the electoral system in Uganda indicate that there is some distance to go for democratic institutions and mechanisms like the EC to develop as a supporting space for fairness, transparency and freedom. A fair, transparent, and free electoral system fosters citizens' trust in the electoral process, particularly, if press freedom is present.[34] A citizenry that trusts its democratic institutions and mechanisms lends legitimacy to those they elect into power and furthermore contributes stability to the state where the citizenry are less inclined to engage in violent protests.[35]

"I think the elections in Uganda produced results exactly as expected....Moving forward, I think it is more important to focus on the process not the election day event. We still have serious reforms that have to be made to make the electoral system fair... There is need for civic education among the masses (not just voter education) to help voters make informed decisions. This will also reduce cases of bribery, intimidation, reduce voter apathy, etc" (Ugandan citizen and local NGO worker, Personal Communication, 10/10/2016).

\section{Variable 3 - Governance and Accountability}

Uganda's level of democracy is considered low, as well as Ugandans' trust in their country's governing institutions.[36] But, the country has come a long way after decades of violent political strife under the rule of despotic leaders. By the time the NRM came into power, the country had an opportunity to rebuild, particularly in terms of its political institutions. Indeed, the country has rebuilt itself and Museveni has been praised for seeing his country through economic growth and political stability. However, the process proved to be fraught with challenges and it also demonstrated a process rife with problematic governance and lack of accountability.

British colonial rule of Uganda made a longstanding impact on the country's social and political structures. The colonial power's political and economic policies helped improve the country's overall infrastructure, but at the cost of a weak local industry and unequal development throughout the country. Furthermore, it contributed to ethnic, racial, class, and regional divides. By the time the country gained independence in 1962, and, although the economy was continuing to do relatively well, it became an environment that mainly privileged the southern region and particularly, the Bagandan ethnic group.[37] After independence, prospects for Uganda's continued economic development deteriorated as the country soon afterwards, fell into a cycle of political turmoil that lasted for over two decades. The dictatorships of Milton Obote, Idi Amin, and very briefly, Tito Okello, destroyed any major hope of a flourishing independent country during their rule. With these political leaders, who hailed from north, in power, the northern region finally obtained better prospects of dominance over the south. All four of Uganda's traditional kingships, including that of Buganda, were dismantled. The economy eventually floundered in the early decades after independence. An overwhelming number of lives were lost during those repressive regimes. By the time Museveni's interim NRM government came into power in the 1980s, the country was in disarray.

One of the first political projects for the NRM was to unite the country. Aware of the challenges they were faced with as a new government, the NRM proposed an ambitious political program that aimed to remove the existing political structures left by the previous governments and replace them with ones that were more economics-focused, populism-centered, and conducive to 
political cooperation. It was called the Ten-point Program, an agenda that declared its intentions to rebuild the country through an inclusive, grassroots democracy, that would unite a previously divided country, build stronger political institutions, and promote greater national economic independence. The initial work that was done appeared to demonstrate some aspects of the 10-point system's aims. As a demonstration of political cooperation and openness to broad-based governing, Museveni recruited leaders of the opposition parties, particularly those that represented the previous regimes, into high ranking government positions (though their political activities were prohibited). Resistance Councils, later called Local Councils, were created to execute governance at the local level, which in their earlier years, proved to be relatively effective in representing and addressing local-level needs. However, the conditions under which the new interim government found itself posed serious challenges to the success of their proposed political agenda. Enduring anxieties--particularly in the North--after years of government-led violence, worries in the north of retaliatory dominance by political leaders from the south, ongoing rebel-led civil wars, and persistent country-wide economic challenges hindered the government from fully implementing its political project. In those initial years, the NRM failed to fully deliver on what it pronounced it would do to rebuild the country, perhaps, partly because of the prohibitive conditions that it found itself in during those initial years of rule.[38] However, as the NRM government gradually gained a stronger footing in the political landscape, it became clear over time, that the incumbent government was actively undermining the governance process and betraying the trust of Ugandan citizens and other political stakeholders for the sake of preserving its own power.

An early sign that Museveni's NRM government intended to strengthen its power was through the strategic political maneuvering that Museveni executed. At the onset of NRM rule, an agreement was made that the NRM would serve as the interim government for four years. When the deadline of its rule drew near, however, Museveni rushed a legislative move through the National Resistance Council (NRC), Uganda's Parliament at the time, to extend the deadline of NRM rule from 1990 to 1995. The move was rushed to last only one week and was seen by some parliamentarians, as blatant disregard for proper legislative procedures. In retrospect, placing a four-year limit to the interim government was an ambitious plan, considering the challenges posed by previous years of war and economic troubles. However, the rushed legislative measure prohibited sufficient public discussion over the matter and greatly undermined parliamentary oversight. In protest to the unscrupulous manner in which the measure passed through legislation, one parliamentarian resigned from his position, becoming the first to do so under such circumstances.[38]

In addition to those nascent signs of decreasing legitimacy of NRM governance, were the freezing effects of political competition. Earlier in Museveni's rule, opposition parties were allowed to exist under the new government, however, their political activities were prohibited. The NRM's official rationale for suppressing political activity was to foster a more united and peaceful political environment. However, it increasingly became an environment where potential competition posed by relatively strong parties like the DP and the UPC were undermined in order to preserve NRM power. Many opposition leaders were placed in high government position, potentially to appease protest. These high positions held by opposition leaders were seen as part of Museveni's attempts to quell prospects of any viable political competition. Meanwhile, opposition party distrust grew as the political landscape increasingly appeared to tilt in favor of NRM dominance.[38]

Another entrenched battleground of mistrust deals with the relationship between the NRM government and the Buganda kingship. The Bugandan kingship was dismantled when Milton Obote seized power and the semi-federal status that it had once enjoyed since independence was revoked. After the NRM government came into power, the issue of restoring Buganda's kingship and its federal status came to the fore but it became a strong point of contention that has continued to this day. In 1990, forty-two Bagandans were arrested on charges of plotting a coup, charges that were largely contested, and had more to do with Museveni's desire to suppress the growing calls for restoring the kingship.[38] Eventually, in 1993, Museveni restored the kinship and returned the land that had been taken away from it during the Obote years. In exchange, Museveni received Bagandan support in the 1995 elections, support that was critical to his prospects for remaining in power because of their majority status in the country, making up nearly $20 \%$ of the population. However, the conditions around the restoration ultimately fell short of the monarchy's expectations. Buganda was restored, but any semblances of its federal status that it enjoyed in previous years were lost. Its political status was relegated merely, to the status of a cultural institution.[39] Public calls for a multi-party system was initially rejected by the NRM government. However, Museveni appeared to realize that submitting to public calls for a multi-party system would actually serve him well. A move to multi-party politics would not only satisfy international donors that were pushing for democratic reform, but it would also serve to strengthen his executive power over the legislature by fracturing oppositional forces within Parliament. Multi-party politics would entail party discipline thereby undermining oppositional coalition-building among the various parties within the legislature. With party discipline in place, political parties would be less inclined to mobilize together across party lines on issues that did not fall in line with their own party's agenda. Further still, along with a concession by Museveni change to a multi-party system, 
the NRM was able to mobilize on a move, possibly through extensive bribery of the legislature, to have presidential term limits removed as part of deal.[24-25]

Ironically, the shift towards multi-party politics rendered the ruling NRM party even more dominant over potential opposition. Not only did the new multi-party system initiate the removal of presidential term limits but it weakened the power of oversight that Parliament had once enjoyed in the one party system. Under Uganda's one-party system, Parliament had a robust political space to contest legislative issues on relatively equal footing with the chief executive. In the early 2000s, Parliament served as a powerful voice of opposition to controversial banking and energy reforms at the time. As the new multi-party system was put into place, Parliament gradually became a heavily fractured legislative body, increasingly divided among party lines. Its capacity to be a viable and cohesive counteracting voice to the president was depleted. This weakened capacity to balance the power of the executive was attributed to a multi-party environment that inhibited coalition-building among the different parties. The strong capacity that members of opposition parties alongside the NRM party had to build strong coalitions on various political issues was a significant feature of Parliament under single-party rule.[24]

A fractured legislative body has been linked to the growing phenomenon of district creation that has served to preserve Museveni's power and NRM dominance over the political landscape. Since the 1990s the creation of new districts has increased at an abnormally high rate throughout the country. In 1994 there were 39 districts, in 2006 there were 80 . More recent numbers reveal 111 districts throughout Uganda.[40] The growing number of districts, particularly within this time frame was observed to be Museveni's method for shoring up political support through the patrimonial opportunities that new districts would provide. As the number districts increased, the amount of support for NRM candidates increased, thus helping to ensure that Parliament seats remain dominated by the NRM party.[40]

Access to justice among the citizenry is an important component of good governance and a strong democracy.[41] The availability of legal council, affordable court costs and public trust that the rule of law would be fairly and effectively exercised, all factor into the degree of access to justice.[45] Uganda ranks relatively low in access to justice. In a 2014-2015 cross-country study of access to justice across the African continent, $45 \%$ of Uganda's population believe that their country's judges are corrupt. The average across the thirty six countries that were studied was $33 \%$. The same study over a larger time span that includes findings from 2005, 2008, and 2011 show that the latest 2015 statistics indicate a recent percentage jump in the population who believe their judges are corrupt. A growing public distrust in the integrity of Uganda's justice system appears to be a recent trend.
Uganda's low degree of justice access is also attributed the large part of its population (36\%) cite high court costs as the main reason why they don't go to court on legal matters.[34] Low quality access to justice among the citizenry further deteriorates public perception of judicial systems that are important institutions for upholding democratic processes.

The political developments in Uganda illustrate a complex dynamic of unchecked executive power that has come to hinder good governance and accountability. The executive and the attendant NRM party demonstrate actions that aim to dominate the political landscape through fracturing a potentially mobilized opposition and through weakening mechanisms that would require this branch of government to answer to the people. Low access to justice and low public confidence on the integrity of the country' judges only undermine public confidence in their political institutions' capacity to hold leaders accountable.

"Democracy is not working in Uganda. There is only rhetoric about it. Leadership is selective, authoritative, and to a big extent dictatorial - in that even when decisions are meant to be discussed and agreed upon by the majority, more often than not, it is by only a few; if not ONE - the Head of State" (Ugandan citizen and local NGO Worker, Personal Communication, 10/10/2016).

\section{Variable 4 - Citizen-Driven Democracy and Civil Society}

Civil society organizations (CSOs) in Uganda have an important role in helping to ensure that its citizens' interests are sufficiently represented in the governance of the country. The landscape of CSOs in Uganda has been relatively active and dynamic and the government has demonstrated its capacity, to some extent, to engage with these organizations. For example, NRM's Parliament structures have traditionally included representation from Nongovernmental Organizations (NGOs). This representation is shown particularly at local levels through the NRM's Local Councils on which NGO representatives sit as committee members. However, the government has shown a long history of holding sway over the CSO landscape to ensure its dominance goes uncontested as much as possible. An early example deals with representation of women's organization and their contributions in drafting Uganda's 1995 Constitution. The Constituent Assembly (CA) was the organization that the government designated responsible for drafting the constitution. It was an assembly of council members that, in principle, contained representation of women's NGOs and other civil society organizations. However, it was an association of members that were elected in a manner that essentially linked them to the larger state structure, thus rendering the CA another organ of the state. Meanwhile, the National Association of Women's Organizations in Uganda (NAWOU) was created as the umbrella 
organization under which all the women-centered NGOs were organized. The NAWOU was conceived as an entity independent of the government, although it wasn't entirely independent as the Ministry of Women in Development still played a facilitating role in its operations. Nonetheless, the NAWO possessed more state-independence than the CA in terms of its relationship to women's NGOs. In selecting CSO contributions through the electoral channels of the CA instead of the NAWOU, the government missed, or altogether ignored the opportunity to include more balanced and independent contributions of women's voices in the constitution-making process.[25]

In recent years, the work of CSOs has increasingly become visible. They have made numerous attempts at ensuring a more democratic electoral landscape. These organizations were able to provide important voter education to Ugandans, they served as domestic observers of presidential and parliamentary elections, and for the 2016 elections, two CSOs, the Elders Forum and the Inter-Religious Council of Uganda (IRCU) helped to organize Uganda's first presidential debates.[26] In 2014, CSOs mobilized together to propose improvements to the legal framework of the electoral system. Their proposals called for better measures of transparency around the appointment of Electoral Committee members, improving political parties' financial accountability and restoring presidential term limits. These calls for change, however, fell on deaf ears. The problematic legal framework of the electoral system remained the same.[26] Uganda's CSOs have served as an important counteracting force to a political landscape on which rests a president that has increasingly become autocratic. However, as much as CSOs could help to develop a political a landscape where citizens' interests are better represented, much of this work have been substantially hindered by various mechanisms of the government. Government's main hindrances have suppressed civil liberties like freedom of association and freedom of expression which have prevented CSOs and regular citizens from effectively coming together to communicate or mobilize on issues that are important to them. The suppressions have been executed mainly by crafting laws that are punitive and prohibitive of activities of assembly and expression on the grounds of preserving the security of Ugandans. It has also been done through invoking existing, but ambiguous laws to actively squash these liberties through arrests, threats and harassment. The Public Order Management Act and the NGO Act are examples of laws that have served to restrict activities of assembly and expression based on security measures. During election rallies, particularly of opposition parties, the Public Order Management Act served useful in justifying harassment and violence by government security personnel against citizens and opposition party members. The NGO Act created a restrictive atmosphere for NGOs to fully and freely execute their activities through difficult registration processes, prohibitive measures on employing foreign nationals and excessive punitive repercussions (for example three years of prison) of NGO employees who were found to be acting against the interests of the country. CSOs that worked particularly in the oil sector, natural resources and governance sector faced substantial surveillance, harassment, arrests on the grounds that they were either causing violence or interfering with the country's development efforts.[26] All these restrictive actions taken by government in response to CSO activities demonstrate attempts to control them and could be seen as the Museveni government's larger project of keeping the landscape tilted in its favor, free from counteractive forces that civil society organizations could present.

The media landscape in Uganda has experienced a long pattern of operating under state restriction and control, with some of the fiercest media control under Amin and Obote's government. However, in the early years of Museveni's rule, he liberalized the landscape for the press. After government assurance of a free press, the number of newspapers blossomed and even those that were critical of government were officially tolerated. This thriving environment for the press only lasted until the late 1990s, when NRM government began to exercise greater control. The Press and Journalist Act, first promulgated in 1995 required journalists to register with the National Institute of Journalists of Uganda (NIJU) and the Media Council. Both these bodies have been accused of lacking independence from the government and have been perceived as attempts to place journalists' conduct under state control. The policy faced heavy opposition from journalists and members of the National Assembly and continues to garner criticism.[43-44] During election cycles, the lack of freedom in press is demonstrated through the self-censorship it exercises in response to intimidation and harassment from state actors. The media coverage of the first presidential debates was observed to tilt positively toward the president. The media landscape in rural areas is particularly entrenched with state control and face even less freedom compared that in urban areas. About $89 \%$ of listeners in rural areas obtain their news from radio which is mainly state-owned. Radio journalists working through local language and who attempt to report on sensitive issues to the NRM have faced threats of suspension or dismissal.[45] In 2013, after two independent news outlets reported on political infighting among NRM members over the president's succession plan, both outlets faced temporary closures and police raids. Media owners have also had to submit to government control on hiring practices and interview programming. One radio station manager was fired after hosting an opposition politician on a talk show in 2014.[44]

Even though CSOs in Uganda have faced a pattern of government action to restrict and control their operations, more recent elections have shown greater engagement among civil society during the election cycles. Some of the observers for the 2011 elections were drawn from local 
communities because of the benefits they provided in their prior knowledge of the local terrain. Door-to-door civic education has been conducted by local observers. They have also reported on illegal polling stations within their localities. Furthermore, new technological innovation have opened up possibilities in voter mobilization campaigns and voter education messaging through social media platforms such as Facebook, Twitter and other websites. CSO's contributions in transparency and accountability have also been supported by technology. In 2011, they were able to report malpractice within the electoral commission through text messaging and postings on websites.[30] However, with the technological innovation and its potentials as attendant support for enabling a free and fair election, the Museveni government has been highly capable of blocking such measures. The 2011 elections occurred as the Mubarak regime in Egypt was toppling and other situations of political unrest with outlash against incumbent power were happening throughout the world. In an attempt to prevent similar unrest and wide-scale protests at home, Museveni and his government worked closely with telecommunication companies to prevent civil society and opposition actors from collecting damning evidence of government-linked malpractice. Text messages that contained such words as, "Cairo", "Mubarak" and "people power" were blocked from being sent and received. Further still, the day after the 2011 elections, the opposition was prevented from tallying results at individual polling stations as the text-messaging system they used to do so, were suspiciously offline.[46-47] More recently, the social media outlets, Twitter and Facebook were banned after opposition candidate, Besigye was arrested during the 2016 election. The rationale given by the president was that, in familiar fashion, security measures had to be taken.[48]

Are Ugandan citizens happy with the way democracy is working in their country? An Afrobarometer study in 2015 found that only $39 \%$ of the population have at least some satisfaction with the democracy they perceive in their country. In term of citizens' demand for democracy, the report's figures seem to indicate a sharp decline in demand from previous years. Demand for democracy had fallen twenty-one points from 2011-2013 demand at 63\% down to $42 \%$ demand in the 2014-2015 time frame. One explanation behind the recent and growing public disillusionment with democracy and the earlier trend of more positive perceptions of democracy may relate to the country's economic growth in the earlier years of the 2000s and the subsequent economic decline in later years. The decline in democratic demand is also linked to the decline in democratic supply. A growing prohibitive political space where the supply of democracy that includes good governance, accountability, a free media, and fair political competition, furthermore seem to inhibit democratic demands in the Uganda.[49]

In spite of the constrictive forces that exist in the
Ugandan political landscape, Uganda's public sphere that encompasses everyday citizens and civil society organizations signal that they continue carry forward their own democratic practices that incessantly place pressure on the government and political leaders. Governing here is not merely done in a pressure-free environment and it is not done without some steering from other forces. Citizen-driven democracy and civil society action illustrate that citizens cannot be always and fully be subjugated by state power or power possessed by other agents.

"Democracy to me is my participation in elections as a citizen, my vote as a social contract, my voice to demand accountability from those I have participated in getting to office" (-Ugandan activist and educator, Personal Communication, 10/10/2016).

\section{Variable 5 - Threats of Extremism, Terrorism and Climate Change}

A 2015 country study on Uganda's fragility status based on a fragility framework encompassing the dimensions of violence, justice, economic foundations, resilience, and institutions, placed Uganda under the category of a fragile state. According to the analysis, Uganda is fragile due to its challenges in the provision of justice, the presence of broad forms of violence and its weak resilience to climate-related, environmental, and social shocks and disasters.[50]

Aside from the LRA insurgency during Museveni's earlier years in power and the al-Shabaab terrorist attacks in 2010, the president has led his country through peace, stability, and a relatively flourishing economy. The threats that LRA and al-Shabaab pose are under relative control. Though there are no imminent threats to the country's security, potential threats of extremism, terrorism and the effects of climate change could undermine the country's fragile peace and stability.

Uganda has largely resisted the recent rise of terror organizations mainly because of its strong military infrastructure. Its military receives substantial support from the US and more generally from the international community which has an interest in maintaining the relatively peaceful conditions amidst turbulent east African neighbors. The LRA is no longer a significant threat, however threats posed by al-Shabaab continues and may grow in significance. Their terrorist activities remain active and Uganda alongside its partners have continued to closely monitor the threats.[51-52] Terrorist threats posed by al-Shabaab are rooted in regional dynamics. As Uganda continues to provide its troops to the African Union' Mission in Somalia (AMISOM), al-Shabaab continues to see Uganda as a threat to its interests in expanding its control throughout Somalia. So long as al-Shabaab perceives Uganda as a threat to its interests for power over Somalia, Uganda would remain a target of its violence.[53]

Climate change effects of frequent droughts and heavy rainfall over the last several decades in Uganda alongside 
poor environmental governance could create conducive conditions for violence. When factors of poor governance and irregular weather patterns interact together with resource scarcity, threats to food security, poor resource management, and deteriorating livelihoods, communities may find themselves in an environment that feeds into the violent potentials of conflict. Inhabitants of the Cattle Corridor in the southwest and northeastern part of the country and the Karamoja sub-region in the north are particularly at risk of facing the dynamic of these forces. Both the Cattle Corridor and Karamoja are inhabited by a pastoralist population whose livelihoods are dependent on the availability of land. However, in an environment that alternates between frequent droughts and torrential downpours effectively rendering swathes of land non-arable, where land rights are contested between local and government actors resulting in land grabbings, and where livelihoods of the local population are deteriorating, local inhabitants find themselves competing over increasingly scarce land and resources. Karamoja's case in particular, illustrates a more problematic phenomenon because of the continued presence of weapons that UPDF soldiers had left behind in the struggle to end Idi Amin's rule. The government's disarmament response throughout the years only increased mistrust of government among the Karamojong as the methods of disarmament reportedly involved beatings, torture, and killings in the hands of the UPDF soldiers. The presence of weapons adds an extra dimension of violence to the potentials of conflict here.[54]

Although the country currently is in a time period of peace, the tensions in the Cattle Corridor and Karamoja both serve as notes of caution alongside the continually active threats that climate change poses to an already multi-dimensional force of conflict drivers. The prospect that Uganda would be able to smoothly recover from potential shocks, whether environmentally or socially related, is shaky. An assessment of the country's vulnerability to disaster indicate that it lacks the coping capacity to reduce negative consequences in the aftermath of disaster.[55] Fragility, weak governance, and political instability are interrelated.[56] If Uganda's atmosphere of relative peace and stability is to be sustained and developed, a range of multifaceted issues would need to be addressed comprehensively. Responding to fragility would require the reduction of violence, the building in public trust in government, and improving the quality of public service and public infrastructure.

\section{Democracy in Progress}

Uganda's elections, to varying degrees, have been blighted with reports of malpractice within the electoral commission, an institution that has already been accused of lacking independence from the executive branch.[30] Furthermore, the current president has shown a history of shaping the political landscape that serve the purpose of consolidating his own power rather than any credible endeavor of consolidating "democracy" itself. Museveni has, however, overseen a political landscape that has enjoyed relative peace, uneasy as it may be. This peace is made uneasy as it continually interacts with such threats posed by extremism, terrorism and the effects of climate change. Further still, the increasingly apparent counter currents of attempts by civil society to ensure transparency and accountability in the electoral process alongside the growth of competition--slow as it may be--among opposing political parties adds an extra dimension of tension countering the actions of a chief executive inclined to preserve his own power. Yet the democratization process of Uganda is likely a gradual and dynamic process and, just as it took time and concerted effort to rebuild the country after decades of political unrest, it will likely take more time and concerted effort by all stakeholders involved to grow the country's democracy. How do Ugandans feel about the way "democracy" is working in their country? One Ugandan gentleman responds:

I can say democracy in Uganda is a work in progress. But at least there is some level of democracy which we can build on. We can say we have a young and growing democracy which we can support to enhance. Regular elections, sound policies, existence of institutions, governance structures from top to lower levels, promotion of citizen participation and a considerable level of civic platform are some of the elements that can be seen towards a growing democracy. The danger is in being young and remaining stunted forever (Personal Communication, 10/08/2016).

\section{Final Thoughts and Further Research Questions}

The majority of the continent's leadership elections over the span of two decades experienced little or no electoral violence (narrowly defined) in the weeks and months immediately around election day. Take, for example, the 2006 elections in Benin. Long-time president Mathieu Kerekou was barred from running again by term limit rules. Kerekou's longtime rival Nicephore Soglo was also barred from standing due to his advanced age. With both of these leading figures excluded, Yayi Boni won the presidency handily in the second round. However, and while this study's purpose was to explore a range of variables that lead to a stronger governance system, higher resiliency and therefore clear linkages between the conduct of peaceful and transparent elections and conflict prevention, it seems relevant to highlight that there is still a dearth of data and empirical evidence as to the clear causes of electoral violence and the motives of political actors for conflict prevention. Looping back to the beginning of the study, it seems likely that persons who, compared to their 
compatriots, discount the supply and positive dividends of democracy in their countries may be more likely to vote against incumbent governments. Thus far, the various contributions to this study have opened up the proverbial 'Pandora's box' as to the anchoring of the term democracy in various African contexts.

Further research questions will need to explore:

- The causes and consequences of differential interpretations of the term democracy and its practices among individuals

- $\quad$ The linkages and varying degrees of effectiveness between some of the explored variables and the outcome of conflict prevention

- The establishment of control variables for each country setting

- A better empirical understanding of the linkages between youth at risk and the threats of radicalization

- $\quad$ The causes and variables of political transitions and the impact on resiliency and conflict prevention

- The relationships between global, elite and local level in fostering a governance environment conducive to the strengthening the culture of participatory decision-making in a new political dispensation

- The role of agency in fostering in- and out-group cohesion and dialogue

Getting a clearer picture of the various in-country factors in relation to regional dynamics will allow to get a better understanding for policy options, development, and the need to foster peace infrastructures (ultimately the state itself) for resilient systems and conflict prevention.

\section{REFERENCES}

[1] Da Rocha J. P. (2015, August). Legitimacy and Resiliency in National Dialogue Processes. Paper presented at public colloquium, BRICS Policy Center, Global South Unit for Mediation, Rio de Janeiro, Brazil. Retrieved from: http://bricspolicycenter.org/homolog/arquivos/Colloquium_ PascaldaRocha.pdf

[2] Carbone, G. (2014). “Elections and Leadership Changes: How do Political Leaders Take (and Leave) Power in Africa?”. Consultancy Africa Intelligence, February 2014.

[3] Freedom House's report Freedom in the World (2016). The Democratic Leadership Gap. Washington, DC: Freedom House. Retrieved June 17, 2016 from https://freedomhouse.org/report/freedom-world/freedom-w orld-2016

[4] Moehler, D., \& Lindberg, S. (2009). Narrowing the Legitimacy Gap: Turnovers as a Cause of Democratic Consolidation. Journal of Politics, 7(4), 1448-1466.

[5] Pastor, R. A. (1999). The role of electoral administration in democratic transitions: Implications for policy and research.
Democratization, 6(4), 1-27.

[6] Beetham, D. (1994). Conditions for democratic consolidation. Review of African political economy, 21(4), 157-172.

[7] Manning, C. (2005). Assessing African Party Systems after the Third Wave. Party Politics, 11(6), 707-727.

[8] Chambers, S. (2001). Constitutional referendums and democratic deliberation. In Mendelsohn, M., \& Parkin, A. (Eds.), Referendum democracy (pp. 231-255). New York, NY: Palgrave Macmillan.

[9] Reynolds, A., Reilly, B., Ellis, A. (2005). Electoral system design: The new international IDEA Handbook. Stockholm, SE: International Institute for Democracy and Electoral Assistance.

[10] Jennings, M. K., \& Niemi, R. G. (1981). Generations and Politics: A Panel Study of Young Adults and Their Parents. Princeton, NJ: Princeton University Press.

[11] Anderson, C. J., A. Blais, S. Bowler, T. Donovan, and O. Listhaug (2005). Losers' Consent: Elections and Democratic Legitimacy. Oxford, UK: Oxford University Press.

[12] Lind, A. E., \& Tyler, T. R. (1988). The Social Psychology of Procedural Justice. New York: Plenum.

[13] Tyler, T. R. (1989). Why People Obey the Law: Procedural Justice, Legitimacy, and Compliance. New Haven, CT: Yale University Press.

[14] Tyler, T. R., Casper, J. D. \& Fisher, B. (1989). Maintaining Allegiance towards Political Authorities: The Role of Prior Attitudes and the Use of Fair Procedures. American Journal of Political Science, 33(3), 629-652.

[15] Kriesberg, L. (2004). Constructive conflicts: From escalation to resolution. Lanham, MA: Rowman and Littlefield.

[16] Kriesberg, L. (2008). Waging Conflicts Constructively. In Sandole, D., Byrne, S., Sandole-Staroste, I., \& Senehi, J. (Eds.), Handbook of Conflict Analysis and Resolution. New York, NY: Routledge.

[17] Fischer, J. (2002). Electoral Conflict and Violence: A strategy for Study and Prevention. IFES White Paper, 1.

[18] Ekeh, P. (1975). Colonialism and the Two Publics in Africa: A Theoretical Statement. Comparative Studies in Society and History, 17, 91-112.

[19] Banégas, R. (1995). Mobilisations sociales et oppositions sous Kérékou. Politique Africaine, 59: 25-44.

[20] Gazibo, M. (2005). Foreign Aid and Democratization: Benin and Niger Compared. African Studies Review, 48(3), 67-87.

[21] Lapalombara, M., \& Weiner, M. (1966). Political Parties and Political Development. Princeton, NJ: Princeton University Press.

[22] Banégas, R. (2003). La démocratie à pas de caméléon. Transition et imaginaires politiques au Bénin. Paris: Karthala.

[23] Banégas, R. (1998). Marchandisation du vote, citoyenneté et consolidation démocratique au Bénin. Politique Africaine, 
69: 75-87.

[24] Keating, M. F. (2011). Can democratization undermine democracy? Economic and political reform in Uganda. Democratization, 18(2), 415-442.

[25] Mujaju, Akiiki. B. (1997). Civil Society at Bay in Uganda. In Georges Nzongola-Ntalaja \& Margaret C. Lee (Ed.), The State and Demoracy in Africa, (pp. 42-52). Trenton, NJ \& Asmara, Eritria: African Association of Political Science.

[26] European Union Election Observation Mission. (2016). Uganda presidential, parliamentary, and local council elections (Final Report). Retrieved 6/7/2016 from http://eeas.europa.eu/eueom/missions/2016/uganda/pdf/uga nda-fr-forprint-14-04-2016_en.pdf

[27] Uganda Bureau of Statistics. (2014). National Population and Housing Census 2014. Retrieved September 7th, 2017 from

http://www.ubos.org/onlinefiles/uploads/ubos/NPHC/NPH C\%202014\%20PROVISIONAL\%20RESULTS\%20REPO RT.pdf.

[28] Human Rights Watch, (2011). World Report 2011. United States. Retrieved 9/1/2016 from:

https://www.hrw.org/sites/default/files/world_report_downl oad/wr2011_book_complete.pdf.

[29] Kiggundu, E. (2016, May 9). Uganda: Where is Amama Mbabazi. The Observer. Retrieved on 9/1/2016 from http://allafrica.com/stories/201605091339.html.

[30] Open Society Foundations. (2015). Election management bodies in east Africa: A comparative study of the contributions of electoral commissions to the strengthening of democracy. Nairobi, Kenya: Mukulilo, A. B., Ntaganda, E., Aywa, F. A., Sekaggya, F., \& Osodo, P. Retrieved June 10, 2016 from:

https://reliefweb.int/report/burundi/election-management-b odies-east-africa-comparative-study-contribution-electoral

[31] International Foundation for Election Systems (IFES). (1996). Uganda: Long term observation of 1996 presidential and legislative elections. Washington DC: Butler, V., Gibson, M. T., Karlstrom, M., Kasfir, N., \& Mburu, C. Retrieved June 6, 2016 from http://ifes.org/publications/uganda-long-term-observation-1 996-presidential-and-legislative-elections-may-july-1996.

[32] Human Rights Watch, (2009). Preparing for the polls: Improving accountability for Electoral Violence in Uganda. New York, NY. Retrieved 9/1/2016 from https://www.hrw.org/sites/default/files/reports/uganda1209 webwcover.pdf

[33] Institute for Security Studies. (2011). Analysis of and reflection on the 2011 elections. Mpyisi, K. \& Mwirichia, V. Retrieved on 6/8/2016 from https://www.issafrica.org/uploads/5May11Uganda.pdf

[34] Afrobarometer. (2017). Public trust in elections: The role of media freedom and election management autonomy. Kerr, N., \& Luhrmann, A. Retrieved March 17, 2017 from: http://afrobarometer.org/sites/default/files/publications/Wor king\%20papers/afropaperno170_public_trust_in_elections. pdf

[35] Norris, P. (2013). Does the world agree about standards of electoral integrity? Evidence for the diffusion of global norms. Electoral Studies, 32(4), 13.

[36] Uddhammar, E. (2011). Supporting the opposition or the ruling party: Stark choices in East Africa. Democratization, 18:5, 1168-1192, DOI:10.1080/13510347.2011.603479.

[37] Kasozi, A.B.K. (1999). The social origins of violence in Uganda: 1964-1985. Kampala: Fountain Publishers.

[38] Brynes, R. M., Library of Congress. Federal Research Division \& Thomas Leiper Kane Collection. (1992). Uganda: A Country Study. Washington, D.C. Retreived on 10/1/2016 from https://www.loc.gov/item/92000513/

[39] Pulford, C. (2014). Two Kingdoms of Uganda. Daventry, GB: Ituri Publications. Retrieved from http://www.ebrary.com.ezproxy.cul.columbia.edu

[40] Green, E.D. (2010), Patronage, district creation and reform in Uganda, Comparative International Development, 45(1), 83-103. doi: 10.1007/s12116-009-9058-8.

[41] United Nations. (2016). Sustainable development knowledge platform. Retrieved March 10, 2017. Retrieved from: https://sustainabledevelopment.un.org/sdg16.

[42] International Commission of Jurists (ICJ). (2009). Access to justice for Africa's marginalized: Impediments and opportunities in eleven countries. Kenyan and Swedish sections of ICJ, African Human Rights and Access to Justice Program.

[43] Tripp, A. M. (2004). The Changing Face of Authoritarianism in Africa: The Case of Uganda. Africa Today 50(3), 3-26. Indiana University Press. doi: 10.1353/at.2004.0035.

[44] Freedom House (2015). Uganda: Freedom of the press country. Freedom House. Retrieved June 20, 2016 https://freedomhouse.org/report/freedom-press/2015/ugand a

[45] Open Society Foundations. (2011). On Air: Uganda. Nairobi, Kenya: Lugalambi, G.W., Mwesige, P.G., Bussiek, H. Retrieved June 10, 2016 from: https://www.opensocietyfoundations.org/sites/default/files/ uganda-public-broadcasting-20100701.pdf

[46] Biryabarema, E. (2011, February 17). Uganda bans SMS texting of keywords during poll. Reuters. Retrieved June 18, 2016 from

http://www.reuters.com/article/ozatp-uganda-election-telec oms-idAFJOE71G0M520110217

[47] Izama, A., \& Wilkerson, M. (2011). Uganda: Museveni's triumph and weakness. Journal of Democracy, 22(3), 64-78. doi: 10.1353/jod.2011.0044.

[48] Duggan, B. (2016, February 19). Uganda shuts down social media; Candidates arrested on election day. CNN. Retrieved June 17, 2016 from

http://www.cnn.com/2016/02/18/world/uganda-election-soc ial-media-shutdown/index.html

[49] Afrobarometer. (2016). Do Africans still want democracy? Mattes, R., \& Bratton, M.. Retrieved March 17, 2017 from http://afrobarometer.org/sites/default/files/publications/Poli cy\%20papers/ab_r6_policypaperno36_do_africans_want_d emocracy.pdf

[50] OECD (2015), States of Fragility 2015: Meeting Post-2015 Ambitions, OECD Publishing, Paris. DOI: 
http://dx.doi.org/10.1787/9789264227699-en

[51] Garamone, J. (2016, June 21). Africom nominee details priorities at confirmation hearing. U.S. Department of Defense. Retrieved June 192016 from http://www.defense.gov/News/Article/Article/808465/afric om-nominee-details-priorities-at-confirmation-hearing

[52] Karimi, F. (2016, February 19). Uganda’s tense election: Five things to know. CNN. Retrieved June 18, 2016 from http://www.cnn.com/2016/02/19/africa/uganda-tense-electi on-5-things-to-know/

[53] Harnisch, C. (2010, July 14). Al Shabaab’s first international strike: Analysis of the July 11 Uganda bombings. American Enterprise Institute. Retrieved June 172016 from: http://www.criticalthreats.org/somalia/al-shabaabs-first-inte rnational-strike-analysis-july-11-uganda-bombings-july-14-
2010-4559

[54] United States Agency for International Development (USAID). (2010, January). Climate change and conflict in Uganda: The cattle corridor and Karamoja. By Stark, J. R etrieved June 16, 2016 from: http://www.fess-global.org/Publications/Other/Climate_Ch ange_and_Conflic_\%20in_Uganda.pdf.

[55] UNU-EHS (2016), World Risk Report 2016, United Nations University Institute for Environmental and Human Security, Bonn, Germany, retrieved from March 15, 2017 from http://collections.unu.edu/eserv/UNU:5763/WorldRiskRepo rt2016_small.pdf.

[56] Gelbard, M. E., \& Xu, R. (2015). Building Resilience in Sub-Saharan Africa's Fragile States. International Monetary Fund. 